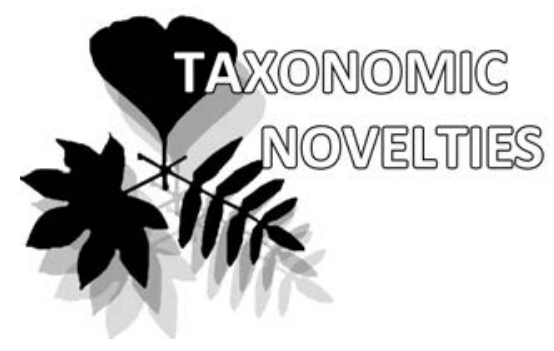

\title{
Notes on Frullania chilcootiensis (Frullaniaceae, Marchantiophyta) with a new synonym, lectotypification and an expanded distribution
}

\author{
John J. Atwood ${ }^{1 *} \&$ Yuriy S. Mamontov ${ }^{2,3}$
}

John J. Atwood ${ }^{1 *}$

e-mail: john.atwood@mobot.org

Yuriy S. Mamontov ${ }^{2,3}$

e-mail: yur-mamontov@yandex.ru

\begin{abstract}
${ }^{1}$ Missouri Botanical Garden, St. Louis, Missouri 63110, U.S.A.

${ }^{2}$ Tsitsin Main Botanical Garden RAS, Moscow, Russia

${ }^{3}$ Polar-Alpine Botanical Garden-Institute RAS, Kirovsk, Russia
\end{abstract}

*corresponding author

Manuscript received: 08.08 .2020

Review completed: 07.09.2020

Accepted for publication: 25.09 .2020

Published online: 27.09.2020

\begin{abstract}
A B S T R A C T
Frullania chilcootiensis Steph. and F. hattoriana J.D. Godfrey \& G. Godfrey are two morphologically similar, little known species from northwestern North America. A Frullania specimen from Washington State, U.S.A. was recently discovered to have affinities with both species. The specimen's shoots show variability in the length of the styli, as well as the number of cells composing them; two key morphological characters previously used to differentiate F. chilcootiensis from F. hattoriana. Based on this overlap and a detailed comparison of the branching and sexuality of the type specimens, F. chilcootiensis and F. hattoriana are here considered to be conspecific, with F. chilcootiensis having priority as the older name. The range of F. chilcootiensis is expanded into western Canada and the continental United States. A lectotype is designated for F. chilcootiensis from among the syntype specimens deposited in FH and $\mathrm{G}$.
\end{abstract}

K e y w o r d s : Frullania cbilcootiensis, F. hattoriana, Frullaniaceae, North America, taxonomy

\section{P E 3 Ю M E}

Атвуд Аж., Мамонтов Ю.С. Заметки о Frullania chilcootiensis (Frullaniaceae, Marchantiophyta) с новым синонимом, Аектотипификацией и расширенным распространением. Frullania chilcootiensis Steph. и F. hattoriana J.D. Godfrey \& G. Godfrey - морфологически сходные, малоизвестные таксоны с Северо-ЗапаАа Северной Америки (первый известен с А^яски, второй - из Британской Колумбии). А^я разграничения этих виАов использовались признаки Алины стилусов и количества клеток в них. В ходе исследования кольекций Frullania в гербарии COLO был выявлен образец из штата Вашингтон (США), который сходен по признакам стилусов с растениями обоих видов. При сравнении типовых образцов этих виАов отмечено их сходство по ряду признаков, а именно по форме и по клеточной сети брюшных и спинных мопастей мистьев, по форме амфигастриев, перианциев и их покровных мистьев. В результате название F. hattoriana включено в синонимы названия F. chilcootiensis как более раннего и приоритетного, ареал последнего вила расширен до Западной Канады и континентальной части США. Выполнена Аектотипификация F. chilcootiensis на основе изученных синтипов из гербариев FН и G.

КАючевые слова: Frullania chilcootiensis, F. hattoriana, Frullaniaceae, Северная Америка, таксономия
Frullania chilcootiensis Steph. and F. hattoriana J.D. Godfrey \& G. Godfrey are two morphologically similar species described from northwestern North America that are considered to be endemics of the upper Pacific Coast Ranges (Hong 1987, Atwood 2017). Frullania chilcootiensis is known from a single southeastern Alaska specimen collected in the late 1800s by brothers Arthur and Aurel Krause, who botanized the Alaskan Panhandle (Hultén 1968), whereas $F$. hattoriana is known from a few relatively recent collections from the southwestern corner of British Columbia. Stephani $(1886,1911)$ described F. chilcootiensis Steph. as a dioicous species, with narrow shoots; ovate dorsal lobes with decurved apices and auriculate antical lobe bases; saccate lobules that are constricted near the mouth; foliaceous styli; and bifid, obovate underleaves with obtusely toothed margins. Evans (1897) treated F. chilcootiensis as an incompletely known species and detailed a brief English description of it based on a drawing and notes that were sent to him by Franz Stephani. Frye and Clark (1947, p.770: 1-3) published a tracing of this drawing and hypothesized that F. chilcootiensis might be a depauperate expression of F. bolanderi Austin, presumably based on similarities of their lobules, foliaceous styli, and underleaves. However, the leafy shoots of F. chilcootiensis are narrower (about 0.36-0.54 mm wide versus $0.9-1.2 \mathrm{~mm}$ wide in F. bolander $)$ and its auriculate lobe base is unlike the truncate lobe base of F. bolanderi. A syntype specimen of F. chilcootiensis in $G$ was examined by Godfrey \& Godfrey (1980) who compared the species to F. hattoriana J.D. Godfrey \& G. Godfrey. Like F. chilcootiensis, F. hattoriana is an epiphyte on bark, has dorsal lobes with rounded apices and auriculate-appendiculate antical bases, saccate lobules and underleaves with a sharp or obtuse tooth on the lateral margins. The species differ in that shoots of F. hattoriana have more branches, an autoicous sexuality 
and longer styli that are also a few cells wider than the styli of F. chilcootiensis. As noted by Godfrey \& Godfrey (1980), newer collections of $F$. chilcootiensis are needed to better understand the morphology of that species.

A Frullania specimen from Washington State, U.S.A., was recently discovered that compares well morphologically with the descriptions of F. chilcootiensis and F. hattoriana in its overall size, as well as characteristics of its leaf lobes, lobules, styli and underleaves. A comparison of this specimen with an isotype specimen of F. hattoriana found that they similarly have long branches that sometimes terminate in gynoecia, and that these slightly diminutive branches are similar in size with the type specimens of F. chilcootiensis. The primary and secondary branches of the F. hattoriana isotype specimen, and the Washington State specimen, also have styli that are shorter and contain fewer cells compared to the styli on their stem. These branch styli are rather similar in length and cell number to the styli in the type specimens of F. chilcootiensis. Lastly, some shoots of the Washington State specimen are diffusely autoicous with the androecia not immediately positioned below the gynoecia. Since the type specimens of F. chilcootiensis are shoot fragments, a remotely located, and therefore unobserved androecia may explain why this species was described as dioicous. Frullania hattoriana is here considered to be conspecific with F. chilcootiensis. The range of F. chilcootiensis is expanded into western Canada and the continental United States. A lectotype is designated for F. chilcootiensis from among its syntype specimens.

\section{MATERIALS AND METHODS}

Syntype specimens of $F$. chilcootiensis deposited in $\mathrm{FH}$ (Fig. 1D, F, I-J, L, M) and G (Fig. 1A-C, E, H, K, N), as well as an isotype specimen of F. hattoriana deposited in UBC (Fig. $1 \mathrm{G})$ were morphologically compared to a newly discovered specimen, Svihla 335 p.p. (deposited in COLO: B-0021088), that was collected in Washington State, United States. The specimen had originally been determined as F. californica (Austin) A. Evans. Morphological measurements were made of the new specimen with particular attention given to the branching pattern, proximity of the androecia and gynoecia, and the number of cells composing the styli, as these characters have been previously emphasized as diagnostic (Frye \& Clark 1947, Godfrey \& Godfrey 1980). The specimens were rehydrated in water and examined using light microscopes equipped with digital cameras. In order to better illustrate the three-dimensional objects, photomicrographs were combined using the stacking software HeliconFocus and then reconstructed into line drawings.

\section{RES U LT S}

Frullania chilcootiensis Steph., Bot. Jahrb. Syst. 8(2): 98. 1886. Type Citation: [U.S.A., Alaska] Hab. Chilcoot, in cortice - Krause nr. 17. 'Type Specimen: [U.S.A.] Alaska, Chilcoot, leg. Krause 17 (G! (G00048046), lectotype designated here); Krause s.n. (FH! (00497817), isolectotype)

= Frullania hattoriana J.D. Godfrey \& G. Godfrey, J. Hattori Bot. Lab. 48: 321. 1980. Type Citation and Specimens: Canada. British Columbia: Vancouver. Mt. Seymour Prov. Pk., Godfrey 1485 (holotype: in personal herb. of J.D. Godfrey and G.A. Godfrey; isotypes: UBC!, NICH).
Canada. British Columbia: Brandywine Falls, ca. $92 \mathrm{~km} \mathrm{~N}$ of Vancouver on Hwy. \#99, Godfrey 2225 (paratype); ca. $24.1 \mathrm{~km} \mathrm{E}$ of Hwy. \#37 crossing over Bear R. at Stuart, ca. $32.2 \mathrm{~km} \mathrm{~W}$ of Cranberry Jct. Rd. intersection, W.B. Schofield 65128 (paratype: UBC), syn nov.

Description. Plants yellowish to pale brown, main leafy shoots up to $1.9 \mathrm{~cm}$ long and $0.45-0.58 \mathrm{~mm}$ wide. Stems rounded, 85-100 $\mu \mathrm{m}$ in diameter, light brown, epidermal cells rectangular and firm-walled, $24-40 \times 6-8 \mu \mathrm{m}$, ventral merophyte approximately $4-5$ cells wide; stem cross-section 5 cells wide with cortical and medullary cell cavities rounded to irregularly oval, $8-12 \times 5-8 \mu \mathrm{m}$, hyaline, sub-equally thickwalled with brown walls. Stems numerously branched, with irregular, pinnate to 3-pinnate branches. Primary branches approximately 3-4 (-7) $\mathrm{mm}$ long and $0.35-0.57 \mathrm{~mm}$ wide, secondary and tertiary branches approximately 2-4 mm long and $0.30-0.37 \mathrm{~mm}$ wide. Stem lateral leaves imbricate, distant to contiguous. Dorsal lobe broadly ovate, 230-385 $\times$ 300-425 $\mu \mathrm{m}$, convex, apex rounded, decurved, margins entire, antical base auriculate-appendiculate, arching across the stem. Marginal cells subquadrate to short-rectangular, 6-10 × 8-12 $\mu \mathrm{m}$, median cells rounded, $10-18 \mu \mathrm{m}$, basal cells more oblong 18-24 × 10-18 $\mu \mathrm{m}$; cells thin-walled, colorless or yellowish brown, with distinct trigones and few intermediate thickenings; oil bodies not seen; ocelli lacking. Lobules always inflated, saccate, 152-210 × 96-132 $\mu \mathrm{m}$ on stem, $130-170 \times 86-110 \mu \mathrm{m}$ on primary and secondary branches, rounded at the apex, constricted near the mouth. Styli foliaceous, 92-145(-200) $\times 85-140 \mu \mathrm{m}$, and composed of 7-12(-15) cells long and 4-6 cells wide on stem; 76-82 $\times 20-30 \mu \mathrm{m}$, and composed of 5-7 cells long and 2-3 cells wide on primary and secondary branches. Underleaves obovate, $220-275 \times 150-180 \mu \mathrm{m}$, bifid to about $0.4-0.5$ times the length, the sinus narrowly acute, the lobes broadly acute to somewhat obtuse, lateral margins obtusely to sharply 1-2 toothed, sometimes entire, bases cuneate. Asexual reproduction not observed. Autoicous, copiously fertile, proximity of androecia and gynoecia variable, the androecia positioned immediately below the gynoecia or located approximately $9-12 \mathrm{~mm}$ below on the stem with the gynoecia located on a branch. Androecia globose, nearly sessile on short lateral branches, with 3-4 pairs of densely imbricate, equally bilobed bracts and 1-2 bracteoles at base. Gynoecia terminal on the stem or primary branch, occasionally on secondary branch. Gynoecial bracts appressed to the perianth, lobe oblong, 420-465 × 170-200 $\mu \mathrm{m}$, apex broadly rounded, entire, subdivided to about 0.5 the length, lobule broadly lanceolate, 380-410 × 120-145 $\mu \mathrm{m}$, apex rounded, with distinct lateral appendage, bracteoles ovate, 360-380 × 165-180 $\mu \mathrm{m}$, bilobed, connate with the bract on one side. Perianth exserted to a little more than half its length, obovate, pluriplicate with 6-9 keels, the beak stout, $110-122 \times 190-208 \mu \mathrm{m}$, with a flared mouth that is partially occluded with papilloid cells. Sporophytes slightly exserted, capsule brown, valves 330-350 $\mu \mathrm{m}$ wide. Elaters 150-180 × $12 \mu \mathrm{m}, 1$-spiralled. Spores reddish brown, 12-15 $\mu \mathrm{m}$ wide.

Specimen examined: U.S.A. Washington State, Pierce County, Mount Rainier National Park, Longmire, 1 September 1931, Svihla 335 p.p. (COLO-B-0021088) 


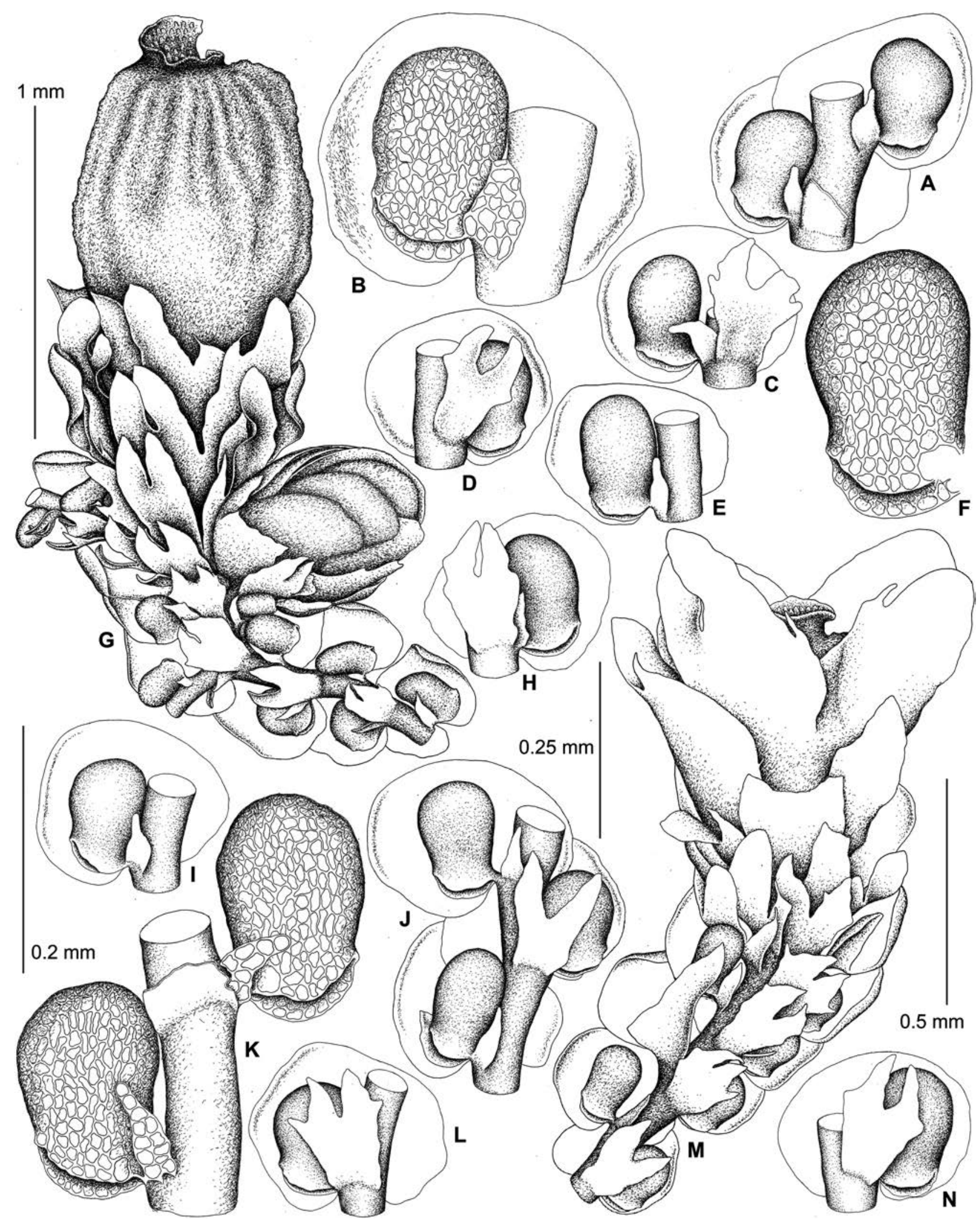

Figure 1 Frullania chilcootiensis Steph. A, C-E, H, I, J, L, N - parts of shoots showing leaves and underleaves. B, F, C - enlarged leaf lobules showing cell outlines. G, M - perianthous shoots. Scale bars: $0.2 \mathrm{~mm}$ for B, K. $0.25 \mathrm{~mm}$ for A, C-E, H, I, J, L, N. $0.5 \mathrm{~mm}$ for M. $1 \mathrm{~mm}$ for G. A-C, E, H, K, N from lectotype of F. chilcootiensis (Krause 17, G). G from isotype of F. hattoriana (Godfrey \& Godfrey 1485, UBC). D, F, I, J, L, M from isolectotype of F. chilcootiensis (Krause s.n., FH) 


\section{DISCUSSION}

The Svibla 335 p.p. specimen, although originally determined as F. californica, is morphologically distinct from that species. Differences from F. californica include its narrower leafy shoots (about $0.45-0.58 \mathrm{~mm}$ wide); the lack of ocelli in the dorsal lobes; the lack of appendiculate styli; and underleaves with toothed, plane margin as well as cuneate bases. By comparison, the leafy shoots of F. californica are about 0.6-0.8 $\mathrm{mm}$ wide and the dorsal lobes tend to have a few, scattered ocelli on at least some leaves, although they may lack them altogether. Furthermore, the styli of F. californica tends to have an appendage, although it can sometimes be reduced, while the underleaves have entire, slightly reflexed margins as well as slightly auriculate bases. The morphological affinities of the Svibla 335 p.p. specimen are instead closer with F. chilcootiensis and F. hattoriana based on their similar branching pattern, and characteristics of their dorsal lobes, lobules styli and underleaves.

The Svibla 335 p.p. specimen has leafy shoots that are branched with pinnate to tri-pinnate branching, similar to the branching pattern of F. hattoriana (Godfrey and Godfrey 1980: Fig. 1, Nos. 1-2). In both the Svibla 335 p.p. specimen and the isotype specimen of F. hattoriana, the branches are somewhat shorter and narrower than the stem. Frye \& Clark (1947) note that one of the defining characters of F. chilcootiensis is its lack of branches. However, the G type specimen is branched, albeit with a single branch. Furthermore, the narrowness of the single shoot comprising the $\mathrm{FH}$ type specimen of $F$. chilcootiensis, and the diminutive size of its lobes and lobules, suggest that it may be a primary or secondary branch rather than a stem. Frullania kunzei (Lehm. \& Lindenb.) Mont., F. tamarisci (L.) Dumort. and F. taxodiocola R.M. Schust. similarly also have comparatively smaller lobes and lobules on their branches versus their stems (Schuster 1992).

In their type comparison, Godfrey \& Godfrey (1980) note that the styli of $F$. chilcootiensis are shorter and narrower than that of $F$. hattoriana. In F. chilcootiensis, the styli length is approximately $1 / 4$ to $1 / 3$ times the lobule length, whereas in F. hattoriana it is about $1 / 2$ to subequal the lobule length. Furthermore, the styli in F. chilcootiensis are about $2-3$ cells wide at their maximum, whereas those of F. hattoriana are 4-6 cells wide at their maximum. The Svibla 335 p.p. specimen has variable foliaceous styli that, on the stem, are about $69-76 \%(-95 \%)$ the length of the stem lobule and are 4-6 cells wide, whereas on the branches are about $48-58 \%$ the length of the branch lobule and are $2-3$ cells wide. The length of the styli on the stem and their number of cells wide is similar and overlaps with the stem styli measurements for F. hattoriana. The length of the styli on the branches is greater than the styli measurements for $F$. chilcootiensis, but the number of cells nevertheless overlaps. In F. hattoriana, the number of cells composing the branch styli also overlaps with the styli of F. chilcootiensis. Variation in the size of the styli, and the number of cells that comprise them have been noted in other Frullania species with foliaceous styli, such as F. bolanderi, F. catalinae A. Evans and F. stylifera (R.M. Schust.) R.M. Schust. Schuster (1992) gives a range from 2-8 cells in his description of the styli base of F. bolanderi. That species can have typical lanceolatetriangular or ovate-lanceolate styli as well as styli on some shoots that are filiforme (Schuster 1992). Mamontov et al. (2020) noted that the styli of F. catalinae varies from foliaceous on sterile well developed shoots to smaller and sometimes inconspicuous on freely fertile shoots. Lastly, in F. stylifera, the foliaceous styli varies from relatively small, (3-) $4-5$ cells wide $(\mathrm{ca} .85 \times 175 \mu \mathrm{m})$ in populations from the European part of Russia, to 8-10 cells wide (ca. 100 $160 \times 250-290 \mu \mathrm{m})$ in south-central Russia populations (Konstantinova et al. 2020).

Lastly, the Svibla 335 p.p. specimen is autoicous with its gynoecia positioned terminally on the stem or on long primary or secondary branches, similar to F. hattoriana. Godfrey \& Godfrey (1980) note that the androecia of F. hattoriana are almost always located near, and positioned below the gynoecia. A similar and corresponding proximal position of the andoecia and gynoecia is found on most shoots in the Svibla 335 p.p. specimen. However, a few shoots have these structures more distantly spaced. On those shoots, the gynoecia are positioned on long branches similar to that illustrated here (Fig. 1M) and by Godfrey \& Godfrey (1980, Fig. 1, No. 1), with the exception that the androecia are located only on the stem. In the Svibla 335 p.p. specimen, the distance between the androecia and gynoecia can be up to $12 \mathrm{~mm}$ apart. Long branches that terminate in gynoecia can give the appearance of dioicy if the androecia are not observed in proximity. A similar condition is found in the southwestern North American endemic F. wrightii Austin. This species, like F. chilcootiensis, was described as dioicous from a shoot fragment (Austin 1872). Numerous morphologically similar specimens have since been found that are diffusely autoicous, with androecia intermittently and only occasionally positioned on the stem or main branch beneath the gynoecia (Atwood 2017).

The Svibla 335 p.p. specimen shows considerable morphological overlap with the type specimens of F. chilcootiensis and F. hattoriana in its branching, as well as characteristics of its dorsal lobes, lobules, styli and underleaves. In light of this specimen, the morphological characters previously emphasized as diagnostic for F. chilcootiensis and F. hattoriana, such as the lack of branches in F. chilcootiensis (Frye \& Clark 1947), and differences in sexuality and the length and number of cells composing the styli for F. hattoriana (Godfrey \& Godfrey 1980) are not taxonomically sufficient to separate these species. Frullania chilcootiensis and F. hattoriana are treated here as synonyms with F. chilcootiensis having priority as the older name. The type specimen of F. chilcootiensis in $\mathrm{G}$ is designated as the lectotype for the species based on its larger size and presence of a branch, in comparison to the type specimen fragment deposited in FH.

The known distribution of F. chilcootiensis is expanded here by approximately $1600 \mathrm{~km}$ to the southeast from the type locality into the continental United States, where the species was collected at $850 \mathrm{~m}$ elevation in a subalpine meadow, mixed with Porella roellii Steph. and Scapania americana Müll. Frib. The type localities of F. hattoriana are separated from the Washington State locality by about $300 \mathrm{~km}$. The holotype and isotype specimens of F. hattoriana 
were collected on bark of a mountain hemlock (Tsuga mertensiana (Bong.) Carr.), in a subalpine forest at about $1000 \mathrm{~m}$ elevation. The species was found in association with Doninia ovata (Dicks.) Buch and Scapania bolanderi Aust.

\section{ACKNOWLEDGEMENTS}

Thanks to COLO, FH and UBC for the loan of specimens. The second author is greatly indebted to M.J. Price and I. Valette for making it possible to study the type of Frullania chilcootiensis at the $G$ herbarium. Nadezhda Konstantinova and an anonymous reviewer improved an earlier version of the manuscript with their edits and comments. The study was partially funded by RFBR, project number 19-04-01270.

\section{LITERAT URE CITED}

Atwood, J.J. 2017. Frullaniaceae. In: Flora of North America north of Mexico, 29 (Bryophyta, part 3), (Flora of North America Editorial Committee, eds), Missouri Botanical Garden. Available from: http://www.mobot.org/ plantscience/BFNA/V3/Frullaniaceae.htm. publ. 6 Dec. 2017. Last accessed 22.09.2020.

Austin, C.F. 1872. New Hepaticae. Bulletin of the Torrey Botanical Club 3:9-18.

Evans, A.W. 1897. A revision of the North American species of Frullania, a genus of Hepaticae. Transactions of the Connecticut Academy of Arts and Sciences 10:1-39, pl. 1-15.
Frye, T.C. \& L. Clark 1947. Frullania. Hepaticae of North America, part V. University of Washington Publications in Biology 6:735-1022.

Godfrey, J.D. \& G.A. Godfrey 1980. Frullania hattoriana, a new hepatic from British Columbia, Canada. Journal of the Hattori Botanical Laboratory 48:321-327.

Hong, W.S. 1987. The distribution of western North American Hepaticae. Endemic taxa and taxa with a North Pacific Arc distribution. The Bryologist 90(4):344-361.

Hultén, E. 1968. Flora of Alaska and neighboring territories. A manual of the vascular plants. Stanford University Press, Stanford, California, 1032 pp.

Konstantinova, N.A., Y.S. Mamontov \& A.A. Vilnet 2020. Frullania stylifera (R.M. Schust.) R.M. Schust. (Hepaticae), new to Eurasia. Journal of Bryology 42(2):152-159.

Mamontov, Y.S., A.A. Vilnet, J.J. Atwood \& N.A. Konstantinova 2020. Molecular phylogenetic study of Frullania subsect. Inflatae (Frullaniaceae, Marchantiophyta) in the Holarctic with description of a new subgenus and three new species. Nova Hedwigia Beiheft 150:201-242.

Schuster, R.M. 1992. The Hepaticae and Anthocerotae of North America east of the Hundredth Meridian, vol. 5. Field Museum of Natural History, Chicago, 854 pp.

Stephani, F. 1886. Hepaticae von der Halbinsel Alaska. Botanische Jahrbucher 8:96-99.

Stephani, F. 1911. Species Hepaticarum, Vol. IV (1909-1912). Georg and Cie, Librarres-fiditeurs, Geneve et Bale. 824 pp. 